\title{
THE EFFECTS OF INTEREST RATE ON REAL EFFECTIVE EXCHANGE RATE VOLATILITY SPILLOVER IN MALAYSIA AND THAILAND: EMPIRICAL EVIDENCE
}

\author{
Mohd Jaffri Abu Bakar', Nanthakumar Loganathan ${ }^{2}$, \\ Tirta Nugraha Mursitama ${ }^{3}$, and Asan Ali Golam Hassan ${ }^{4}$ \\ ${ }^{1,2,4}$ Azman Hashim International Business School, Universiti Teknologi Malaysia, \\ 54100 Kuala Lumpur, Malaysia \\ ${ }^{3}$ International Relations Department, Faculty of Humanities, \\ Bina Nusantara University, Jakarta, Indonesia 11480 \\ 1'mohdjaffri@graduate.utm.my; 2n4nantha@yahoo.com; \\ 3tmursitama@binus.edu; ${ }^{4}$ asanali@utm.my
}

Received: $26^{\text {th }}$ June 2021/ Revised: $17^{\text {th }}$ December 2021/ Accepted: $17^{\text {th }}$ December 2021

How to Cite: Bakar, A. M. J., Loganathan, N., Mursitama, T. N., \& Hassan, A. A. G. (2021). The effects of interest rate on real effective exchange rate volatility spillover in Malaysia and Thailand: Empirical evidence. Journal of ASEAN Studies, 9(2), 181-198. https:/doi.org/ 10.21512/jas.v9i2.7517

\begin{abstract}
The research examined this asymmetric effect between the interrelationship of the interbank rate on the external competitiveness purchasing power represented by the real effective exchange rate for Malaysia and Thailand using monthly data covering the period of 1994 until 2020. The empirical findings confirms an asymmetric effect between interbank rate and real effective exchange rate based on the nonlinear autoregressive distributed lag estimates. The research also finds a unidirectional asymmetric causal relationship running from real effective exchange rate on interbank rate Thailand, which indicate the monetary policy has a direct relationship on interbank rate volatility. While in Malaysia, there is no causality running between both variables since the country has proposed several soft monetary policies and more concentrating on the short-term borrowing by improving the tight money supply circulation based on the domestic inflation, global economic, and financial market volatility. Therefore, the research recommends a specific need of monetary stabilizer policy to stabilize both countries' currencies and put more effort to liberalize the foreign exchange rate system in a globalized economy.
\end{abstract}

Keywords: asymmetric analysis, interest rate, nonlinear causality, real effective exchange rate 


\section{INTRODUCTION}

The internationalization wave has made the country purchasing power indicators become one of the most widely studied macroeconomic indicators in the world. These indicators gauge the value of imports and exports between countries by determining the intrinsic purchasing power of a country with respect to its trading partners. Thus, the stabilization of purchasing power indicators have become one of the main objectives of monetary policy for most countries, especially among Asian countries (Cobham, 2021). The monetary policy is a powerful tool used by a country's authority to regulate macroeconomic and financial indicators such as the inflation rate, the exchange rate conversion, and the employment rate. The policy is formulated using different tools such as interest rate, government securities, and reserve to control the amount of money circulated in the market.

Since 1950, Malaysia has employed multiple targeting monetary policies to avoid price volatility, spur economic growth and maintain financial stability without elucidating potential conflicts and trade-offs - in-line with the charter objectives of the Central Bank of Malaysia (Cheong, 2005; Ariff \& Yap, 2001). Malaysia has also adopted the soft monetary policy, however, since the 1997 Asian financial crisis, the monetary policy committee of the Central Bank of Malaysia has embedded financial stability as one of the country's monetary policy objectives. The principal objective of monetary policy as per Central Bank of Malaysia Act of 2009 is to develop a conducive monetary and financial stability to support economic growth (Hossain, 2017).

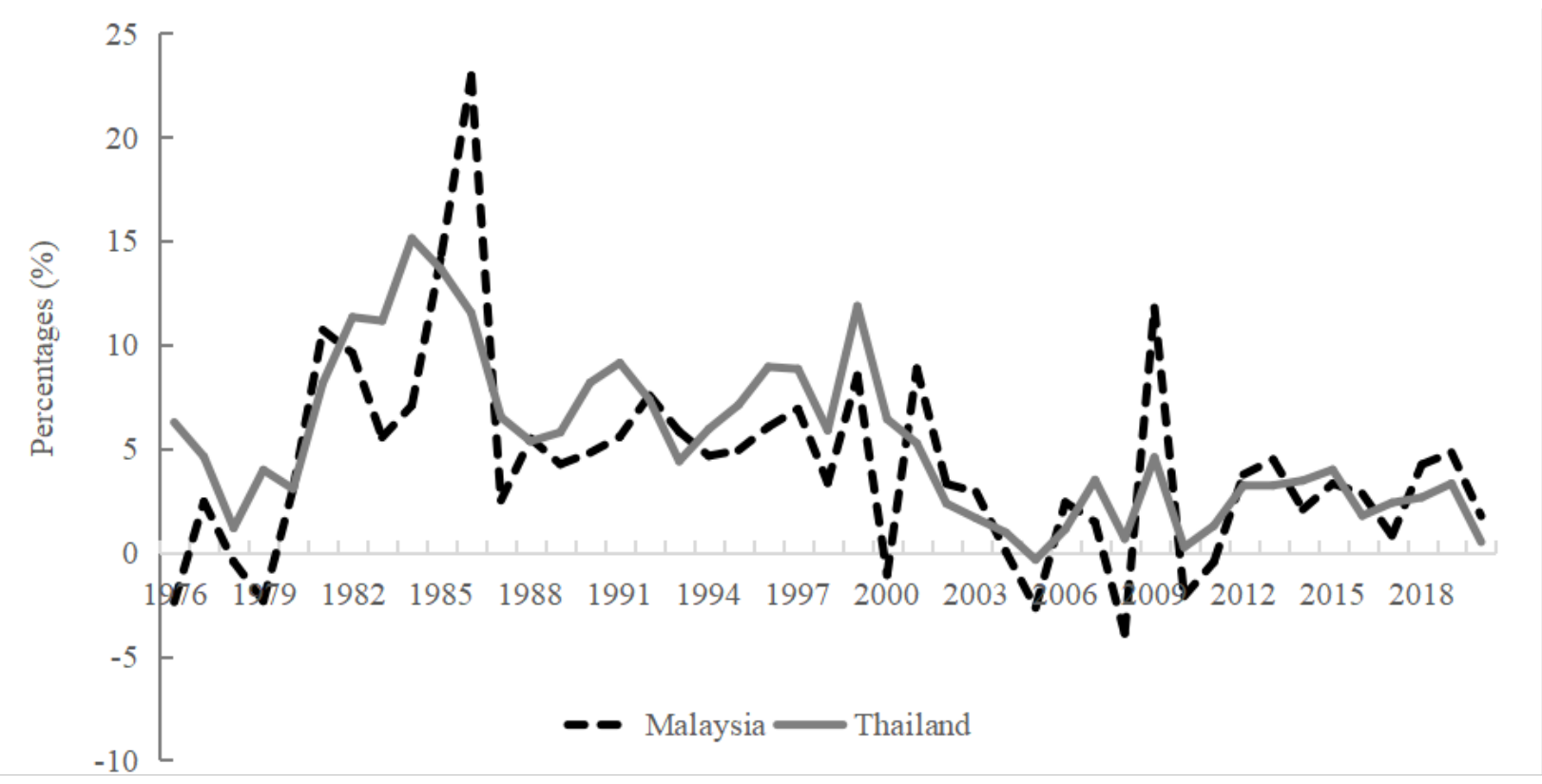

Figure 1. The trend of real interest rate for Malaysia and Thailand between 1976 to 2020 Source: World Bank (2021) 


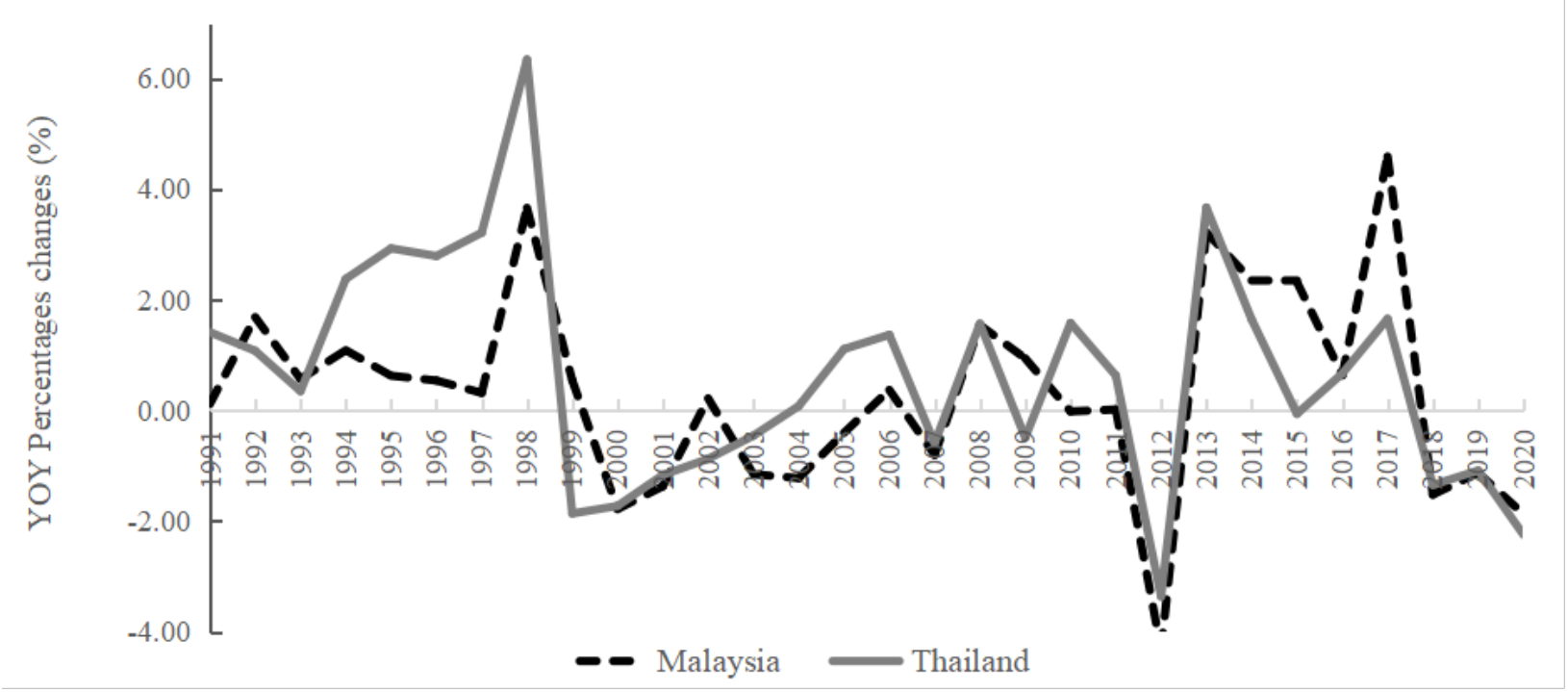

Figure 2. The trend of PPP conversion factor (private consumption) for Malaysia and Thailand between 1991 to 2020 .

Source: World Bank (2021)

Thailand monetary policy framework is slightly different compared to that of Malaysia, whereby the Thailand government has undergone three phases of regime development until now. The first phase started after the end of World War II with the Baht value being pegged to the gold value, major currencies or a basket of currencies. The second phase of monetary targeting regime took place with the adoption of the floating exchange rate system starting in 1997 with the financial support and monitoring by the International Monetary Fund (IMF); with the objectives to maintain the macroeconomic stability, ultimate sustainable growth, and price consistency. The third phase began on May 2000 by employing flexible inflation targeting with the main focus on the price stability and inflation rate framework supporting the sustainable economic growth (Bank of Thailand, 2020; McCauley, 2006).

Figure 1 and Figure 2 show the trend of selected macroeconomic variables for Malaysia and Thailand for the past few decades. Generally, the interbank rate and external competitiveness purchasing power of Malaysia and Thailand were quite volatile and this created an atmosphere of economic uncertainty even though they have recovered from the 1997 Asian Financial Crisis (AFC). Undeniably, the instability of these indicators can dampen the economic growth if not properly managed by the relevant authorities. Although previous studies have documented the relationship and impact between these variables, the empirical findings show mixed results, with different directions and arguments on sampling and exchange rate regimes issues. Thus, the main objective of this study is to examine the interrelationship between interest rate (IBR) and external purchasing power indicator for Malaysia and Thailand. 


\section{LITERATURE REVIEW}

Generally, it is believed that higher interest rate can significantly contribute to the stabilization of purchasing power indicators. However, the possible trade-off from the higher interest rates includes fragile financial system, production loses, and higher unemployment rate. Sarac and Karagöz (2016) and Furman et al. (1998) point out that, although some scholars opined that interest rate can play a role in stabilizing the purchasing power indicators, the empirical validation of its effectiveness remains inconclusive until to date. However, interest rate parity theory states that the difference between domestic and foreign interest rates equals to the supply and demand of the change in the exchange rate, so no party could misuse the interest rate differential to create arbitrage profit due to depreciated currency of the countries with high interest rate (Wu \& Cheng, 1998). Although there have been many research on the effectiveness of monetary policies and interest rate, Kayhan et al. (2013) argue that the interest rate in emerging, developing, and developed economies behaves differently and has varying impacts on the same type of purchasing power indicators. Recently, Karamelikli and Karimi (2020) have used the linear and nonlinear estimates, which result in different empirical statistics and relationships between interest rate and purchasing power indicators in Turkey.

The movement of interest rate due to the short-term borrowing and money supply circulation in the market by the government authority reflects the volatility in purchasing power performance. Interest rate and purchasing power indicators are interrelated to play a role in stabilizing the growth and development in the country. Therefore, lower interest rate promotes growth of money in the market, which results in an increase in spending and thus promotes development; but at the same time causes inflation rate to increase (Oliver, 1997). Due to the effect of monetary policy changes on the volatility purchasing power indicators, many studies attempted to investigate the relationship between these variables using assorted models and econometric approaches. For example, Hoang et al. (2020), Cecchetti et al. (2020), Alsamara and Mrabet (2019), Aizenman et, al. (2016) and Bagchi, Chortareas, and Miller (2004) have explained the impact of monetary policy on the changes in value of purchasing power indicators.

Moreover, Brailsford et al. (2006) also indicate that many Asian countries' exchange rate benefit from the interest rate fluctuation especially during the financial crisis. In addition, Curran and Velic (2019) and Patel and Mah (2018) have found that the monetary policy tools as well as interest rate have a strong causal relationship with the real external purchasing power indicators in the emerging countries. AbuDalu and Ahmed (2014) find a significant relationship between interest rate and competitiveness exchange rate indicator performances in Thailand. Andonov et al. (2017), Hanson and Stein (2015), and Bowe and Saltvedt (2004) show that interest rate is an important factor that attracts foreign investment flows, and this can be achieved through interest rate manipulation by the authorities.

Interest rate volatility, however, can affect the ion volatility of inflation rate and a country's internal purchasing power. Pattanaik and Mitra (2001) prove that inflation rate, interest rate, and external purchasing power are highly correlated with each other. Sun and De 
(2019) postulate that the depreciation of external purchasing power rate seems to create an inflationary effect in the US due to the circulation of money in the market as compared to quantity production. The situation will spark arbitrage activities as a result of profit arising from the disequilibrium price between countries. Ahmed and Mazlan (2021) update the finding of ASEAN countries by revealing that the effect of interest rate on the external purchasing power indicator varies with the existence of short run and long run asymmetries within ASEAN members. According to Phuc and Duc (2019), although inflation volatility, trade openness, and interest rate significantly influence changes of external purchasing power indicators in Australia, Japan, New Zealand and South Korea, the impact varies across the studied sample.

Similarly, Barbosa et al. (2018) proves varying impacts of selected independent variables on the volatility purchasing power indicators in developing and emerging countries. Nonetheless, the impact of interest rate on purchasing power indicators especially real exchange rate movement is still ambiguous. Kalemli-Ozcan and Verela (2019) provide an evidence of weak influence on the impact of interest rate differentials on purchasing power indicators in emerging countries. Hnatkovska (2013) concludes that the impact of interest rate on external purchasing power indicators vary, and is dependent on the variation of interest rate, especially for Thailand. Moreover, Tari and Abasiz (2009) reveal that the causal relationship between the external purchasing power indicator and interest rate is just valid in the short run. In contrast, Khin et al. (2017) and Sarac and Karagöv (2016) provide an evidence of non-significant relationship between external purchasing power indicator and interest rate especially in a long-run relationship for Malaysia and Turkey. Interestingly, Engel et al. (2019) have recently found the importance of inflation rate on the volatility of exchange rate rather than the interest rate in the case of US dataset. Table 1 indicates some of the previous studies capturing the causal relationship between external purchasing power and interest rate worldwide.

Table 1. Causal Relationship between External Purchasing Power Indicators and Interest Rate

\begin{tabular}{lcccc}
\hline \multicolumn{1}{c}{ Authors } & Time Span & Country & Method & Causality \\
\hline $\begin{array}{l}\text { Balduzzi and Chiang } \\
(2020) .\end{array}$ & $1983-2012$ & Emerging countries & VECM & EPPIs $\leftarrow /-$ IR \\
Nguyen et al. (2020) & $1999-2014$ & ASEAN countries & SVAR & EPPIs $\leftarrow /-$ IR \\
Hoang et al. (2020) & $2005-2018$ & Vietnam & VAR & EPPIs $-/ \rightarrow$ IR \\
Sun and De (2019) & $1973-2017$ & US & FAVAR & EPPIs $-/ \rightarrow$ IR \\
Alsamara and Mrabet & $1986-2014$ & Turkey & Linear and & EPPIs $-/ \rightarrow$ IR \\
(2019) & $1981-2013$ & Asian countries & GMM & EPPIs $\leftarrow /-$ IR \\
Draz et al. (2019) & $2010-2016$ & Malaysia & VECM & EPPIs $\leftarrow \neq \rightarrow$ IR \\
Khin et al. (2017) & $1980-2011$ & OECD countries & BEER & PPIs $\leftarrow /-I R$ \\
Adler and Grisse (2014) & $1989-2006$ & Emerging countries & VAR & PPIs $-/ \rightarrow$ IR \\
Aizenman et al. (2011)
\end{tabular}

Source: Author's compilation 
Alsamara and Mrabet (2019) and Chowdhury (2012) have found that external purchasing power indicators are negatively related with interest rate differential and money supply in Turkey and Australia, respectively. Moreover, Bagchi et al. (2004) also find that real interest rate differential has a long-run pressure impact on Australia's real purchasing power indicators, and the pressure impact may change due to the different exchange rate regimes implemented. Furthermore, Engel (2019) and Draz et al. (2019) also prove that the interest rate indicator has significant impact on the volatility of real purchasing power indicators in selected Asian economies. Kia (2013) finds that the money supply, interest rate, growth rate, government expenditure, commodity prices, and debt have significant impact on the volatility of purchasing power indicators in Canada. Furthermore, Andries et al. (2017) and Granville and Mallick (2010) provide empirical evidence of a robust relationship between interest rate and external purchasing power indicators in Romania and Russia, respectively.

Verico (2017) suggests that in order for ASEAN Economic Community (AEC) to be economically integrated, the private sector in the ASEAN countries needs to be strengthened. Understanding the complex relationship between monetary policies especially interest rate and purchasing power indicators is crucial because the disequilibrium between the variables can have a big impact to country sustainable economic growth and development. However, previous empirical findings documented mixed results with different direction and argument on sample observation, exchange rate regime and the macroeconomic indicators used. Therefore, this research fulfils the gap by employing the asymmetric empirical analysis to get a comprehensive outcome focusing on the emerging ASEAN's small tigers, mainly Malaysia and Thailand.

\section{RESEARCH METHODS}

The research analysis relies on monthly data from January 1994 to December 2020. The data on external purchasing power indicators, which is represented by the real effective exchange rate (REER), are obtained from J. P. Morgan's time series data sources ("Data and analytics", 2021). Meanwhile, the data for interest rate based on the IBR were obtained from the Central Bank of Malaysia (2021) and the Bank of Thailand (2021). The REER is a proxy for the external purchasing power indicator and is the dependent variable in the research. This indicator represents the intrinsic value of comparing exchange rate fluctuation on the quantity of goods and services offered internationally between local currency and other currencies as suggested by Bartolli (1995). In order to obtain a specific relationship between the external purchasing power indicator and interest rate, a general empirical model specification is created:

$$
\mathrm{REER}=f(\mathrm{IBR})
$$

The REER and the IBR are transformed into natural logarithm formation to avoid bias estimation. Based on the nature of the time series data, the research firstly performs several 
unit root tests to ensure the tested variables are free from stationary problems, and at the same time, appropriated econometrical models are chosen. The unit root tests performed include: 1) the Augmented Dickey Fuller (ADF), proposed by Dickey and Fuller (1981), 2) Kwiatkowski-Phillips-Schmidt-Shin test (KPSS) by Kwiatkowski et al. (1992), 3) the endogenous structural break stationarity test by Perron (1989), and 4) the nonlinearity test of the Fourier ADF (FADF) test proposed by Enders and Lee (2012). The FADF nonlinear unit root test is used because the REER series may entail structure breaks due to the exchange rate regimes implemented during the period of the study (peg exchange rate regime and managed floating regime). Furthermore, the nonlinearity test based on the FADF is also utilized to capture the nonlinearity condition of the tested variables. The auto-regressive distributed lag (ARDL) cointegration approach introduced by Pesaran et al. (2001) is utilized, and it uses the F-statistics value against the upper and lower critical bounds value for the cointegration decisions. In general, the ARDL cointegration model for the research can be defined as follows:

$\Delta R E E R_{t}=\varphi_{0}+\sum_{i=1}^{p} \varphi_{11 i} \Delta R E E R_{t-i}+\sum_{i=0}^{p} \varphi_{12 i} \Delta I B R_{t-i}+\gamma_{11} R E E R_{t-1}+\gamma_{12} I B R_{t-1}+\mu_{1 t}$

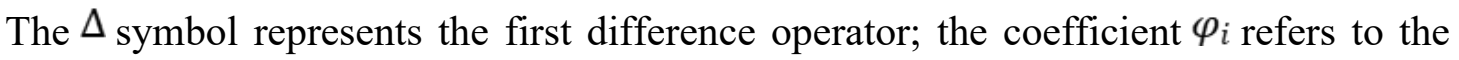
short-run elasticities; $\gamma_{i}$ represents the long-run elasticities; and $\mu_{t}$ indicates the normal white noise of the ARDL estimates. The aim is to determine the long-run cointegration between REER and the IBR. Therefore, the null hypothesis can be expressed as $H_{0}: \gamma_{11}=\gamma_{12}=0$, with the alternative hypothesis expressed as $H_{1}: \gamma_{11} \neq \gamma_{12} \neq 0$. Pesaran et al. (2001) formulate critical value based on the F-statistic is used in the research. If the estimated Fstatistic is higher than the upper bounds $I(1)$, it indicates that there is a long-run cointegration between the estimated series of this research. For the purpose of ARDL bounds estimation, the Akaike Information Criterion (AIC) to select the optimal lag for estimation purposes (Yakubu et al., 2021) is employed.

Considering the assumption of limited information revealed by the symmetric model in permitting the strong inference for yielding a predictable forecast in wide range of economic and finance situations, the nonlinear ARDL (NARDL) test is performed to explore the actual long run relationship between external purchasing power indicator and interest rate in Malaysia and Thailand. Based on Shin et al. (2014), the positive and negative components in the test will capture the existence of asymmetric relationships of underlying variables. Shin et al. (2014) defines the equation of positive and negative components as presented:

$$
i v_{t}^{+}=\sum_{j=1}^{t} \Delta i v_{j}^{+}=\sum_{j=1}^{t} \max \left(\Delta i v_{j}, 0\right)
$$




$$
i v_{t}^{-}=\sum_{j=1}^{t} \Delta i v_{j}^{-}=\sum_{j=1}^{t} \min \left(\Delta i v_{j}, 0\right)
$$

Therefore, the NARDL specification can be written as follows:

$$
\begin{aligned}
\triangle R E E R_{t}= & \alpha_{0}+\beta_{0} R E E R_{t-1}+\beta_{1} I B R_{t}^{+}+\beta_{2} I B R_{t}^{-}+\sum_{t=1}^{p} \mu_{t} \Delta R E E R_{t-1}+ \\
& \sum_{t=1}^{q}\left(\gamma_{t}^{+} I B R_{t-1}^{+}+\gamma_{t}^{+} I B R_{t-1}^{-}\right)+\varepsilon_{t}
\end{aligned}
$$

The $i v ' s$ are the independent variables and the parameter $p$ and $q$ are lag order. In order to examine the cause-effect relationship, the Hatemi-J causality test as used by Nguyen et al. (2015) and Gozgor (2014) is used to capture the possibilities of the asymmetric effect relationship between external purchasing power indicator and interest rate. Hatemi-J (2012) proposes the equation as presented:

$$
\begin{aligned}
& y_{1 t}=y_{1 t-1}+\varepsilon_{1 t}=y_{10}+\sum_{i=1}^{t} \varepsilon_{1 t} \quad t=1,2 \ldots T \\
& y_{2 t}=y_{2 t-1}+\varepsilon_{2 t}=y_{20}+\sum_{i=1}^{t} \varepsilon_{2 t} \quad t=1,2 \ldots T
\end{aligned}
$$

where, $y_{10}$ and $y_{20}$ are the constant value, $\varepsilon_{1 i}$ and $\varepsilon_{2 i}$ are white noise disturbance term, $\varepsilon_{1 i}^{+}=\max \left(\varepsilon_{1 i}, 0\right), \varepsilon_{2 i}^{+}=\max \left(\varepsilon_{2 i}, 0\right), \varepsilon_{1 i}^{-}=\min \left(\varepsilon_{1 i}, 0\right)$, and $\varepsilon_{2 i}^{-}=\min \left(\varepsilon_{2 i}, 0\right)$, represent the positive and negative parameter. This can also be expressed as $\varepsilon_{1 i}=\varepsilon_{1 i}^{+}+\varepsilon_{1 i}^{-}$ and $\varepsilon_{2 i}=\varepsilon_{2 i}^{+}+\varepsilon_{2 i}^{-}$. This can be rewritten based on the presented expressions:

$$
\begin{aligned}
& y_{1 t}=y_{1 t-1}+\varepsilon_{1 t}=y_{1,0}+\sum_{i=1}^{t} \varepsilon_{1 i}^{+}+\sum_{i=1}^{t} \varepsilon_{1 i}^{-} \\
& y_{2 t}=y_{2 t-1}+\varepsilon_{2 t}=y_{2,0}+\sum_{i=1}^{t} \varepsilon_{2 i}^{+}+\sum_{i=1}^{t} \varepsilon_{2 i}^{-}
\end{aligned}
$$

The positive and negative value for each variable will be defined as a cumulative form as $y_{1 t}^{+}=\sum_{i=1}^{t} \varepsilon_{1 i}^{+}, y_{1 t}^{-}=\sum_{i=1}^{t} \varepsilon_{1 i}^{-}$and $y_{2 t}^{+}=\sum_{i=1}^{t} \varepsilon_{2 i}^{+}, y_{2 t}^{-}=\sum_{i=1}^{t} \varepsilon_{2 i}^{-}$. Thus, each underlying variable has a permanent impact of positive and negative shocks. After that, the test of causal relationship between variables done by the VAR model of order $p$ value:

$$
\begin{gathered}
y_{1}^{+}=v+A_{1} y_{t-1}^{+}+\ldots+A_{p} y_{t-1}^{+}+\mu_{t}^{+}, \text {by assuming } y_{t}^{+}=\left(y_{1 t}^{+}, y_{2 t}^{+}\right) ; \text {and } \\
y_{1}^{-}=v+A_{1} y_{t-1}^{-}+\ldots+A_{p} y_{t-1}^{-}+\mu_{t}^{-}, \text {by assuming } y_{t}^{+}=\left(y_{1 t}^{-}, y_{2 t}^{-}\right)
\end{gathered}
$$


where, the $y_{t}^{+/ 1}$ is the $(1 \times 2)$ vectors of the variable, $v$ is the $(1 \times 2)$ vectors of intercepts, $\mu_{\mathrm{t}}^{+/-}$is the $(1 \times 2)$ vectors of error terms and $A_{r}$ is the $(2 \times 2)$ matrix of parameter for lag order $r=1 \ldots, p$ and the lag order selection will based on the AIC specification.

\section{RESULTS AND DISCUSSIONS}

Table 2 summarizes the test statistics for the employed unit root tests. The ADF and PP unit root test statistics show that all variables are stationary in their level, but become nonstationary after taking the first difference, whereas the KPSS unit root test statistic demonstrates a non-stationarity in level and stationary in first difference. Thus, all variables are confirmed stationary in first difference despite using a multiple traditional unit root test and endogenous structure break unit root test. However, the Fourier ADF unit root test shows that the REER variables for Thailand has a unit root issue. Thus, this warrants the utilization of ARDL and NARDL approach since the unit root tests statistics are mixed.

Table 2. Unit Root Test Results

\begin{tabular}{|c|c|c|c|c|c|c|c|}
\hline & \multicolumn{3}{|c|}{ At level } & \multicolumn{3}{|c|}{ At first difference } & \multirow{2}{*}{ FADF } \\
\hline & ADF & KPSS & Perron & ADF & KPSS & Perron & \\
\hline \multicolumn{8}{|c|}{ Malaysia } \\
\hline REER & $-2,299$ & $1,050 *$ & $\begin{array}{c}-3,066 \\
\text { (1998; Nov) }\end{array}$ & $-17,177^{*}$ & 0,046 & $\begin{array}{c}-17,344 * \\
(1997 ; \text { Dec })\end{array}$ & $-2,443$ \\
\hline IBR & $-2,021$ & $0,803 *$ & $\begin{array}{c}-2,801 \\
(2002 ; \text { Feb })\end{array}$ & $-13,917 *$ & 0,085 & $\begin{array}{c}-8,872 * \\
(1999 ; \text { Jan })\end{array}$ & $-2,233$ \\
\hline \multicolumn{8}{|c|}{ Thailand } \\
\hline REER & $-2,040$ & $0,632 * *$ & $\begin{array}{c}-4,573 \\
(2000 ; \text { Dec })\end{array}$ & $-16,171 *$ & 0,108 & $\begin{array}{c}-8,137 * \\
(1998 ; \text { Feb })\end{array}$ & $-4,721 *$ \\
\hline IBR & $-1,686$ & $1,212 *$ & $\begin{array}{c}-3,054 \\
(2001 ; \text { Sept })\end{array}$ & $-7,545 *$ & 0,059 & $\begin{array}{c}-10,780 * \\
(1998 ; \text { Nov })\end{array}$ & 1,033 \\
\hline
\end{tabular}

Note: $*$ and $* *$ denote rejection of the null hypothesis of a unit root at the 1 and $5 \%$ significance levels, respectively. The finite sample critical values for FADF and F-test are taken Table 1 of Enders and Lee (2012).

Furthermore, the result of ARDL bounds test confirms that there is no long-run relationship between interest rate and purchasing power indicator being studied (see Table 3). In Malaysia, there is an endogenous break for REER in November 1998 and for IBR on February 2002, respectively. This could be due to the Asian financial crisis in 1998, where Malaysia manipulated the interest rate policy and increased the government spending in order to stimulate economic growth ("Malaysia: December 2001", 2001). Thailand encountered the REER endogenous break in December 2000, and IBR in September 2001. These periods referred to changes of Thailand monetary policy which stressed exchange rate stability and fostering an economic recovery. In addition, it is also attributed to the victory of Telecoms tycoon Thaksin Shinawatra's Thai Rak Thai Party in Thailand general election ("Timeline: Thailand's turbulent", 2019). 
Table 3. Bounds Test for the ARDL and NARDL Cointegration Specifications

\begin{tabular}{cccc}
\hline & \multicolumn{2}{c}{$F$-statistics } & \multirow{2}{*}{ Results } \\
\hline ARDL & Malaysia & Thailand & No cointegration \\
NARDL & 2,064 & 1,484 & Cointegrated \\
\hline Significance & $4,088^{*}$ & $3,605^{*}$ & \\
value & \multicolumn{2}{c}{ Critical values } \\
\cline { 2 - 3 } $1 \%$ & Lower bounds & Upper bounds & \\
$5 \%$ & 4,94 & 5,58 & \\
$10 \%$ & 3,62 & 4,16 & \\
\hline
\end{tabular}

Note: * denote rejection of the null hypothesis of no long run cointegration at $1 \%$ significance level. The lag selection is based on the AIC.

In addition, the empirical results are parallel with Abdoh et al. (2016) which also reveal that there is no long-run relationship between interest rate and exchange rate for Brunei, Malaysia, Philippines, Singapore, Thailand, Indonesia, Cambodia, Laos, and Vietnam, using the symmetric cointegration approach. In addition, when the nonlinear ARDL test is used, a significant long-run relationship between the series of both countries are found. This result is in-line with Karamelikli and Karimi (2020), and Katrakilidis and Trachanas (2012). In Golit et al. (2019), an asymmetric approach was used in examining the sample of G7 countries, which showed a stronger relationship between interest rate and exchange rate.

The findings on the long run and short run asymmetric estimates are presented in Table 4. For Malaysia, the findings verifies the existence of long run asymmetry positive effect of IBR on the REER. When the IBR increases in the long-run period, the REER decreases by almost $22,1 \%$. Looking at Thailand, the estimation confirmed a significant relationship for both of positive and negative asymmetric effects especially in the short-run. An increase of IBR in the short-run period is able to increase the REER around $13,4 \%$, and decreases in IBR will reduce the REER value around $12 \%$. For Thailand, the NARDL estimates indicate the overall positive effect around $0,1 \%$ higher compared to the negative effect faced by the country.

Table 4. The NARDL Estimates

\begin{tabular}{|c|c|c|c|}
\hline Country & Variable & Coefficient & $F$-statistics \\
\hline \multirow{4}{*}{ Malaysia } & $L_{I B R}^{+}$ & $-0,221$ & $3,75 * * *$ \\
\hline & $L_{I B R}$ & 0,112 & 1,473 \\
\hline & $W_{L R, I B R}$ & \multicolumn{2}{|c|}{$7,832 *$} \\
\hline & $W_{S R, I B R}$ & \multicolumn{2}{|c|}{0,534} \\
\hline \multirow{4}{*}{ Thailand } & $L_{I B R}^{+}$ & 0,134 & $3,289 * * *$ \\
\hline & $L_{\overline{I B R}}^{-}$ & $-0,120$ & $4,137 * *$ \\
\hline & $W_{L R, I B R}$ & \multicolumn{2}{|c|}{0,416} \\
\hline & $W_{S R, I B R}$ & \multicolumn{2}{|c|}{$19,750^{*}$} \\
\hline
\end{tabular}

Note: $* * *$ and $* * *$ denote rejection of the null hypothesis of no asymmetric relationship at the 1,5 and $10 \%$ significance level, respectively. The lag selection is based on the AIC. 
Figure 3 depicts the long-run dynamic multiplier effects with positive and negative changes in IBR for Malaysia and Thailand over the estimation period of the research. It is found that approximately after the third period, the solid line of asymmetric effect in Malaysia indicates decreased condition with almost four periods before it rises and overshoots positive and negative effects during the fourth period, and consistently facing constant condition over the estimation period. The negative changes showed by the dotted line have crossed-out the asymmetric line at the $13^{\text {th }}$ period, which is approximately in year 2000 due to the recovery effect of Asian financial crisis and the economic recession period for many developed countries in the early 2000s. Thus, an increase of IBR has a long run negative effect on the REER in Malaysia. However, there is a different situation with the dynamic multiplier effects in Thailand, where the positive effect overshooting the asymmetric line for all periods are involved in the research. Hence, an increase in IBR totally has a positive effect on the REER since the country has overcome the financial issues with a comprehensive tight monetary policy over the estimation period.

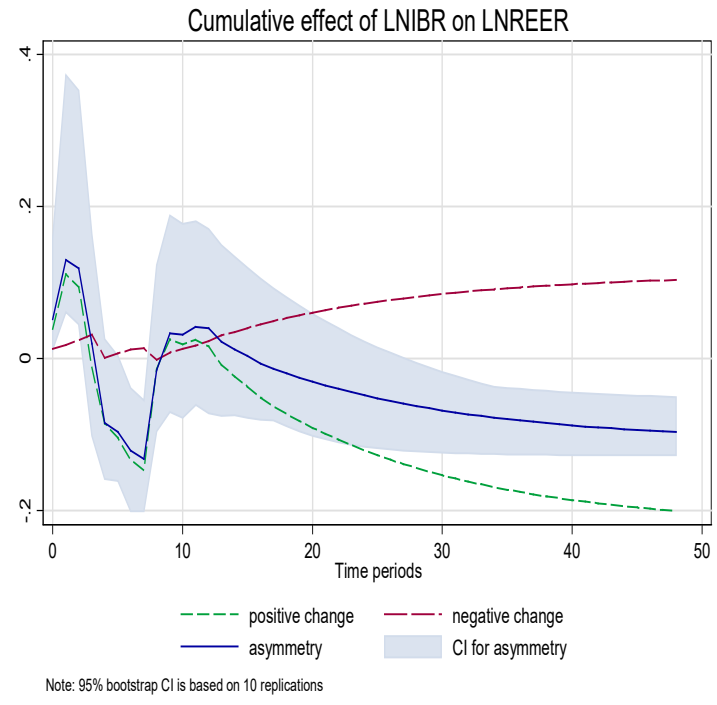

(a) Malaysia

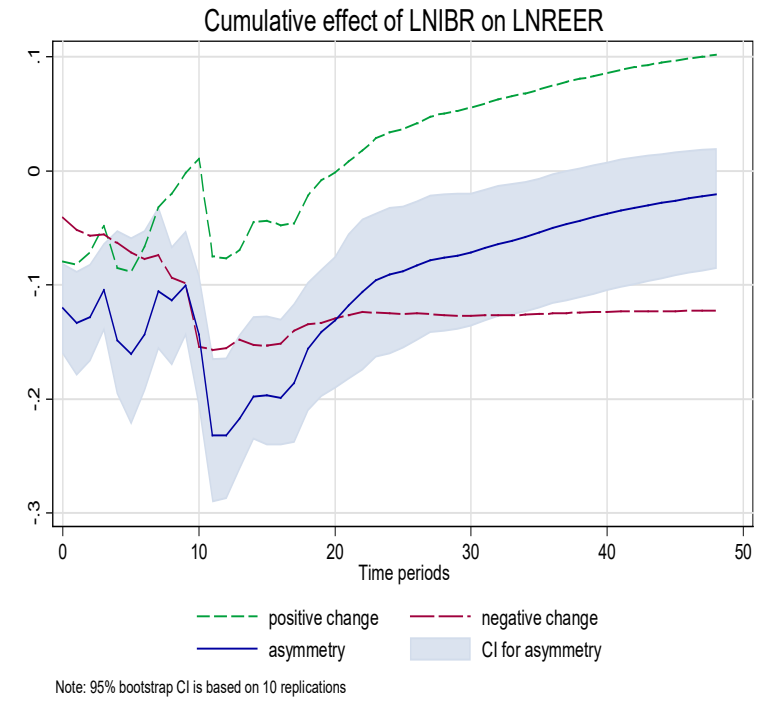

(b) Thailand

Figure 3. Asymmetric Effect of IBR on REER for Malaysia and Thailand

In order to validate the asymmetrical relationship between interbank rate and real effective exchange rate, the research performs the Hatemi-J (2012) asymmetric causality test, and the summary of the causal effect tests are reported in Table 5. Based on the estimation, the research found that there is no asymmetric causal relationship between IBR and the REER in Malaysia. However, there are two coefficient values that are statistically significant, and this proves the existence of asymmetric causal relationship between IBR and the REER for Thailand. This is especially in the situation where positive components of real effective exchange rate cause the positive components of IBR; and negative components of the REER cause the negative components of IBR. The research findings are almost in-line with those of 
Karamelikli and Karimi (2020) and Capasso et al. (2019), which confirm that the short and long run relationship with positive and negative explanatory power of the IBR components is greater than positive explanatory components.

Table 5. Hatemi-J Asymmetric Causality Test Results

\begin{tabular}{lcccc}
\hline \multirow{2}{*}{ Causality directions } & \multicolumn{2}{c}{ Malaysia } & \multicolumn{2}{c}{ Thailand } \\
\cline { 2 - 5 } & W-statistics & Null hypothesis & W-statistics & Null hypothesis \\
\hline$I B R \rightarrow R E E R$ & 0,011 & Accept & 0,727 & Accept \\
$I B R \leftarrow R E E R$ & 0,542 & Accept & 0,554 & Accept \\
$I B R^{+} \rightarrow R E E R^{+}$ & 0,564 & Accept & 0,976 & Accept \\
$I B R^{+} \leftarrow R E E R^{+}$ & 1,084 & Accept & $6,257^{* *}$ & Reject \\
$I B R^{-} \rightarrow R E E R^{-}$ & 0,247 & Accept & 0,696 & Accept \\
$I B R^{-} \leftarrow R E E R^{-}$ & 1,869 & Accept & $6,979^{* *}$ & Reject \\
\hline Note: $*{ }^{* *}$ and $* * *$ denote rejection of the null hypothesis of no causality at the 1,5 and $10 \%$ significance \\
\multicolumn{2}{l}{ level, respectively. }
\end{tabular}

\section{CONCLUSIONS}

The interrelationship between IBR and purchasing power indicator, especially the REER, has become an important and complex issue for stakeholders. According to the interest rate parity theory, interest rate affects the real exchange rate in short time horizon and becomes reversed in the long run. The assumption of the interest rate parity theory is particularly true in emerging economies, especially when the countries' authorities attempt to stabilize and manage the exchange rate volatility through monetary policy tools. The research provides new evidence in explaining the interrelationship between IBR and purchasing power indicator in the context of Malaysia and Thailand. It has been proven that there is an existence of asymmetric interrelationship between the interest rate and purchasing power indicator variables. The Malaysian data reveal that the asymmetric long-run cointegration between variables and the negative explanatory components of IBR variation have a greater effect on the variation of the REER. On the contrary, Thailand data reveal that an asymmetric short-run interrelationship and the positive explanatory components of IBR variation have greater effect than negative explanatory components. Moreover, Thailand data support the assumption of IBR affects the REER on a short time horizon and reverse on the long-time horizon as explained by the interest rate parity theory.

An increase of interest rate, especially the short-term interest rate, causes a depreciation to the Malaysian purchasing power indicator value for long time period, but appreciates the Thailand purchasing power indicator value in a short period. Thus, due to the asymmetric relationship, the countries' authorities, especially the central banks of both countries, should be more cautious on the dynamic interrelationship between IBR and purchasing power indicators in designing future monetary policy strategies especially in the global financial liberalization scenario. Although only Thailand shows an asymmetric causal relationship, the volatility of interbank rate and real exchange rate has a huge impact on the country's future economic development. Counterbalance of money supply changes is the best 
tool in achieving some combination of exchange rate fluctuation and output stabilization. Despite the available number of strategies, the loosening or tightening of interest rate term is an effective option that can be implemented in the exchange rate open market operation in achieving both price and output objectives.

\section{ABOUT THE AUTHORS}

Mohd Jaffri Abu Bakar is a current enroll as a Doctoral (PhD) student in Azman Hashim International Business School, Univeristi Teknologi Malaysia (UTM). His research interests include financial issues relate to economics.

Nanthakumar Loganathan is currently attached with Azman Hashim International Business School, Universiti Teknologi Malaysia as Associate Professor in Development Economics. He also has been appointed as a Visiting Professor for Bina Nusantara University. His research focuses mainly relate development economics, tourism, and resource economics which relate to time series modelling.

Tirta Nugraha Mursitama is a Professor of International Business at International Relations Department, Faculty of Humanities, Bina Nusantara University. His research interests include internationalization strategy of the firms, digital economy, and economic integration in Southeast Asian countries.

Asan Ali Golam Hassan is a Professor of Economics at enroll with Azman Hashim International Business School, Universiti Teknologi Malaysia. His research focus concentrates on economic planning related to government policies and research activities worldwide.

\section{ACKNOWLEDGEMENT}

The research is funded under the Fundamental Research Grant Scheme (FRGS) from the ministry of Higher Education Malaysia (Vote Number: FRGS/1/2020/SS0/UTM/02/10). We would also like to thank Universiti Teknologi Malaysia (UTM) for the continuous support for the successful completion of this research.

\section{REFERENCES}

Abdoh, M. M. Y., Yusof, M. N. H., Zulkifli, M. S. A, Bulot, N., \& Ibrahim, N. J. (2016). Macroeconomic factors that influence exchange rate fluctuation in ASEAN countries. International Academic Research Journal of Social Science, 2(1), 89-94.

AbuDalu, A. \& Ahmed, E. M. (2014). The determinants of ASEAN-5 real effective exchange rate vis-ávis the UK pound. World Journal of Entrepreneurship, Management and Sustainable Development, 10(2), 98-118. 
Adler, K. \& Grisse, C. (2014). Real exchange rates and fundamentals: Robustness across alternative model specifications. SNB Working Papers 7/2014.

Ahmed, H. F. T. \& Mazlan, N. S. (2021). The impact of interest rate on exchange rate within ASEAN countries: Evidence from linear and nonlinear framewirks. Global Journal of Emerging Market Economies, 13(1), 7-34. https://doi.org/10.1177\%2F0974910120974798

Aizenman, J., Chinn, M. D., \& Ito, H. (2016). Monetary policy spillovers and the trilemma in the new normal: Periphery country sensitivity to core country conditions. Journal of International Money and Finance, 68, 298-330. https://doi.org/10.1016/j.jimonfin.2016.02.008

Aizeman, J., Hutchison, M., \& Noy, I. (2011). Inflation targeting and real exchange rates in Emerging markets. World Development, 39(5), 712-724.

Alsamara, M., \& Mrabet, Z. (2019). Asymmetric impacts of foreign exchange rate on the demand for money in Turkey: New evidence from nonlinear ARDL. International Economics and Economic Policy, 16(2), 335-356. https://doi.org/10.1007/s10368$\underline{018-0421-y}$

Andonov, A., Bauer, R. M., \& Cremers, K. M. (2017). Pension fund asset allocation and liability discount rates. Review of Financial Studies, 30(8), 2555-2595. https://dx.doi.org/10.2139/ssrn.2070054

Andries,, A. M., Capraru, B., Ihnatov, I., \& Tiwari, A. K. (2017). The relationship between exchange rates and interest rates in a small open emerging economy: The case of Romania. Economic Modelling, 67, 261-274. https://doi.org/10.1016/j.econmod.2016.12.025

Ariff, M. \& Yap, Meow-Chung, M. (2001) Financial crisis in Malaysia. In T.-S. Yu and D. $\mathrm{Xu}$ (Eds.), East Asia Rising Again. Singapore: World Scientific Publishing.

Bagchi, D., Chortareas, G. E., \& Miller, S. M. (2004). The real exchange rate in small, open developed economies: Evidence from cointegration analysis. Economic Record, 80(248), 76-88. https://doi.org/10.1111/j.1475-4932.2004.00126.x

Balduzzi, P. \& Chiang, I. E. (2020). Real exchange rate and currency risk premiums. The Review of Asset Pricing Studies, 10(1), 94-121.

Bank of Thailand (2020). Development of monetary policy framework in Thailand. https://www.bot.or.th/English/MonetaryPolicy/MonetPolicyKnowledge/Pages/Frame work.aspx

Bank of Thailand. (2021). Interest rates. https://www.bot.or.th/english/statistics/_layouts/application/interest_rate/in_rate.aspx 
Barbosa, L. O. S., Jayme, F. G. Jr., \& Missio, F. J. (2018). Determinants of the real exchange rate in the long-run for developing and emerging countries: A theoretical and empirical approach. International Review of Applied Economics, 32(1), 62-83. https://doi.org/10.1080/02692171.2017.1332017

Bartolli, L. (1995). Purchasing power parity measures of competitiveness. Finance and Department, 32(3), 46-49. https://doi.org/10.5089/9781451952193.022

Bowe, M., \& Saltvedt, T. M. (2004). Currency invoicing practices, exchange rate volatility and pricing to market: Evidence from product level data. International Business Review, 13(3), 281-308. https://doi.org/10.1016/j.ibusrev.2004.01.003

Brailsford, T., Penm, J. H. W., \& Lai, C. D. (2006). Effectiveness of high interest rate policy on exchange rates: A reexamination of the Asian financial crisis. Advances in Decision Sciences, 4, 1-9. https://doi.org/10.1155/JAMDS/2006/35752

Capasso, S., Napolitano, O., \& Jiménez, V. A. L. (2019). The long run interrelationship between exchange rate and interest rate; the case of Mexico. Journal of Economic Studies, 46(7), 1380-1397. https://doi.org/10.1108/JES-04-2019-0176

Cecchetti, S. G., Grifoli, T. M., Narita, M., \& Sahay, R. (2020). US or domestic monetary policy: Which matters more for financial and stability? IMF Economic Review, 68, 35-65. https://doi.org/10.1057/s41308-020-00108-2

Central Bank of Malaysia. (2021). Interest rates and volumes. https://www.bnm.gov.my/interest-rates-volumes

Cheong, L. M. (2005). Globalization and the operation of monetary policy in Malaysia. BIS Papers, 23, 209-215.

Chowdhury, K. (2012). Modelling the dynamics, structural breaks and the determinants of the real exchange rate of Australia. International Financial, Markets, Institution and Money, 22(2), 343-358. http://dx.doi.org/10.1016/j.intfin.2011.10.004

Cobham, D. (2021). A comprehensive classification of monetary policy frameworks in advanced and emerging economies. Oxford Economic Papers, 73(1), 2-26. https://doi.org/10.1093/oep/gpz056

Curran, M., \& Velic, A. (2019). Real exchange rate persistence and country characteristics: A global analysis. Journal of International Money and Finance, 97, 35-56. https://doi.org/10.1016/j.jimonfin.2019.06.001

Data and analytics. (2021). J. P. Morgan. https://www.jpmorgan.com/solutions/cib/securitiesservices/data-analytics

Dickey, D. A., \& Fuller, W. A. (1981). Likelihood ratio statistics for autoregressive time series with a unit root. Econometrica, 49(4), 1057-1072. https://doi.org/10.2307/1912517 
Draz, M., Ahmad, F., Gupta, B., \& Amin, W. (2019). Macroeconomic fundamentals and exchange rates in South Asian economies. Journal of Chinese Economic and Foreign Trade Studies, 12(2), 104-119. https://doi.org/10.1108/JCEFTS-01-2019-0007

Enders, W., \& Lee, J. (2012). The flexible fourier form and Dickey-Fuller type unit root tests. Economics Letters, 117(1), 196-199. https://doi.org/10.1016/j.econlet.2012.04.081

Engel, C. (2019). Real exchange rate convergence: The roles of price stickiness and monetary policy. Journal of Monetary Economics, 103, 21-32. https://doi.org/10.1016/j.jmoneco.2018.08.007

Furman, J., Stiglitz, J. E., Bosworth, B. P., \& Radele, S. (1998). Economic crises: Evidence and insights from East Asia. Brookings Papers on Economic Activity, 2, 1-135.

Golit, P., Salisu, A., Akintola, A., Nsonwu, F., \& Umoren, I. (2019). Exchange rate and interest rate differential in G7 Economies. Bulletin of Monetary Economics and Banking, 22(3), 263-286. http://dx.doi.org/10.21098/bemp.v22i3.1147

Gozgor, G. (2014). Causal relation between economic growth and domestic credit in the economic globalization: Evidence from the Hatemi-J's test. The Journal of International Trade \& Economic Development, 24(3), 395-408. https://doi.org/10.1080/09638199.2014.908325

Granville, B., \& Mallick, S. (2010). Monetary policy in Russia: Identifying exchange rate shocks. Economic Modelling, 27(1), 432-444. https://doi.org/10.1016/j.econmod.2009.10.010

Hanson, S. G. \& Stein J. C. (2015). Monetary policy and long-term real rates. Journal of Financial Economics, 115, 429-448. http://dx.doi.org/10.1016/j.jfineco.2014.11.001

Hatemi-J, A. (2012). Asymmetric causality tests with an application. Empirical Economic, 43, 447-456. https://doi.org/10.1007/s00181-011-0484-x

Hnatkovska, V., Lahiri, A., \& Vegh, C. A. (2013). Interest rate and the exchange rate: A nonmonotonic tale. European Economic Review, 63, 68-93. https://doi.org/10.1016/j.euroecorev.2013.06.001

Hoang, V., Nguyen, D. K., \& Pham, T. A. (2020). On the effects of monetary policy in Vietnam: Evidence from a trilemma analysis. The World Economy, 1-34. https://doi.org/10.1111/twec.13025

Hossain, A. A. (2017). Monetary policy for maintaining low, stable inflation in Malaysia. The Journal of Developing Areas, 51(2), 381-404. https://doi.org/10.1353/jda.2017.0052

Kalemli-Ozcan, S. \& Varela, L. (2019). Exchange Rate and Interest Rate Disconnect: The Role of Capital Flows, Currency Risk and Default Risk. Meeting Papers 351, Society for Economics Dynamics 
Karamelikli, H. \& Karimi, M. S. (2020). Asymmetric relationship between interest rates and exchange rate: Evidence from Turkey. International Journal of Finance and Economics, 1-11. https://doi.org/10.1002/ijfe.2213

Katrakilidis, C. \& Trachanas, E. (2012). What drives housing price dynamics in Greece: New evidence from asymmetric ARDL cointegration. Economic Modelling, 29(4), 10641069. https://doi.org/10.1016/j.econmod.2012.03.029

Kayhan, S., Bayat, T., \& Ugur, A. (2013). Interest rates and exchange rate relationship in BRIC-T countries. Ege Academic Review, 13(2), 227-236.

Khin, A. A., Yee, C. Y., Seng, L. S., Wan, C. M., \& Xian, G. Q. (2017). Exchange rate volatility on macroeconomic determinants in Malaysia: Vector error correction method (VECM) model. Journal of Global Business and Social Entrepreneurship, $3(5), 36-45$.

Kia, A. (2013). Determinants of the real exchange rate in a small open economy: Evidence from Canada. Journal of International Financial Markets, Institutions and Money, 23, 163-178. https://doi.org/10.1016/j.intfin.2012.09.001

Kwiatkowski, D., Phillips, P. C. B., Schmidt, P., \& Shin, Y. (1992). Testing the null hypothesis of stationarity against the alternative of a unit root. Journal of Econometrics, 54(1-3), 159-178. https://doi.org/10.1016/0304-4076(92)90104-Y

McCauley, R. N. (2006). Understanding monetary policy in Malaysia and Thailand: Objectives, instruments and independence. BIS Papers chapters. In Bank for International Settlements (Ed.), Monetary Policy in Asia: Approaches and Implementation, 31, 172-196.

Nguyen, D.K., Sousa, R.M., \& Uddin, G.S. (2015). Testing for asymmetric causality between U.S. equity returns and commodity futures returns. Finance Research Letters, 12, 3847. https://doi.org/10.1016/j.frl.2014.12.002

Nguyen, N., Harvie, C., \& Suardi, S. (2020). ASEAN income gap and the optimal exchange rate regime. Applied Economics, 52(3), 1-17. https://doi.org/10.1080/00036846.2019.1645278

Oliver, V. (1997). Early beginnings of the beginning of the quantity theory of money and their context in Polish and Prussian monetary policies. Economic History Reviews, 50(3), 430-449. https://doi.org/10.1111/1468-0289.00063

Patel, D. \& Mah, G. (2018). Relationship between real exchange rate and economic growth: the case of South Africa. Journal of Economics and Behavioral Studies, 10(1), 146158. https://doi.org/10.22610/jebs.v10i1(J).2098

Pattanaik, S. \& Mitra, K. A. (2001). Interest rate defense of exchange rate: Tale of the Indian rupee. Economic and Political Weekly, 36, (46/47), 4418-4427. 
Perron, P. (1989). The great crash, the oil price shock, and the unit root hypothesis. Econometrica, 57, 1361-1401. https://doi.org/10.2307/1913712

Pesaran, M. H., Shin, Y., \& Smith, R. J. (2001). Bounds testing approaches to the analysis of level relationships. Journal of Applied Econometrics, 16, 289-326. https://doi.org/10.1002/jae.616

Phuc, N. V., \& Duc, V. H. (2019). Macroeconomics determinants of exchange rate passthrough: New evidence from the Asia-Pacific region. Emerging Markets Finance and Trade, 1-16. https://doi.org/10.1080/1540496X.2018.1534682

Saraç, T. B. \& Karagöz, K. (2016). Impact of short-term interest rate on exchange rate: The case of Turkey. Procedia Economics and Finance, 38, 195-202. https://doi.org/10.1016/S2212-5671(16)30190-3

Shin, Y., Yu, B., \& Greenwood-Nimmo, M. (2014). Modelling Asymmetric Cointegration and Dynamic Multipliers in a Nonlinear ARDL Framework. In W. Horrace, \& R. Sickles (Eds.), The Festschrift in Honor of Peter Schmidt: Econometric Methods and Applications (pp. 281-314). Springer.

Sun, W. \& De, K. (2019). Real exchange rate, monetary policy, and the U.S. economy: Evidence from a FAVAR model. Economic Inquiry, 57(1), 552-568. https://doi.org/10.1111/ecin.12723

Tari, R. \& Abasiz, T. (2009). Frequency domain approach and short-run and long run causality test: Evidence from Turkey for interest rate and exchange rate relationship. METU Studies in Development, 36(2), 405-421.

Timeline: Thailand's turbulent politics over two decades. (2019, March 22). Reuters. https://www.reuters.com/article/us-thailand-election-timeline-idUSKCN1R30HR

Verico, K. (2017). The key factors of economic integration in Southeast Asia: Case of Indonesia, Malaysia and Thailand. Journal of ASEAN Studies, 4(2), 107-126.

Yakubu, Z., Loganathan, N., Sethi, N., \& Golam Hassan, A. A. (2021). Do financial development, trade openness and political stability complement for Egypt's economic growth? Journal of International Commerce, Economics and Policy, 12(1). https://doi.org/10.1142/S1793993321500010

World Bank. (2021). World Development Indicators. Retrieved from http: www.worldbank.org.

Malaysia: December 2001. (2001, December 05). World Trade Organization. https://www.wto.org/english/tratop_e/tpr_e/tp180_e.htm

Wu, J. L. \& Chen, S. L. (1998). A re-examination of real interest rate parity. The Canadian Journal of Economics, 837-851. 